\title{
Preserving Javanese Culture by Junior Highschool Students in Northern Semarang District as Javanese Language Environment to Promote Local Tourism Industry
}

\author{
Wiwiek Sundari ${ }^{1, *}$ \\ ${ }^{1}$ Department of Linguistics, Faculty of Humanities, Diponegoro University, Semarang - Indonesia
}

\begin{abstract}
Culture is system of idea and act as a result of human creation. A culture becomes history when their community leave it. A language, as part of culture, becomes dead when a speech community leave it. Preserving culture and language is important to keep our identity and civilization. This research shows how Javanese speech community keep their use of Javanese to maintain their culture in Northern Semarang as Javanese environment by taking the data from Junior Highschool students. The result shows that most of them still maintain Javanese, especially the lowest level of Javanese (Ngoko) to talk to their friend in casual situation. Few of them understand the highest level of Javanese (Krama) to honor the older. They are also able to write and read Javanese letters since it is taught as a school subject with local content. Javanese language and culture maintenance is supported by the local government to promote Semarang tourism industry to gain more benefit for the local people and the local government. Preserving culture by maintaining the language must be supported by the environment by using it in daily conversation and teaching it in school to make the young generation understand and use the language.
\end{abstract}

Keywords: culture; language; language environment; Javanese; preserve; tourism industry

\section{Research Background}

Culture is a whole system of idea, act and a result of human creation in their social life [1]. As it is inherited, created or learned, human can have a culture from their ancestor, from their own creation or from learning a culture. As human act in their life is done by learning, it can be said that human act is part of their own culture. One of human culture resulted from learning process is language. It is learned through daily conversation at home in the language speech community supported by the language environment. Language can also be learned by a learning process at school.

One of the benefit of learning a language is to keep the culture using the language as a dead culture can be a history when their owner have gone or abandon the culture and a dead language becomes archaic when their users have also gone or neglect the language. Therefore, preserving a culture and the language embeded in it is beneficial to keep the cultural identity of the community and the environment. Another benefit of maintaining the culture and the language is to support the local tourism industry, especially the cultural, historical and traditional tourism like the old city or the villages offering cultural, traditional and historical tourism. As the tourism business revolution leads to cultural, traditional and historical tourism, preserving Javanese culture and language is beneficial for gaining profit for local people involved in the tourism industry and the local government.
One of ways to preserve a culture is done by using the language in it, especially by the young generation who will be the future generation of the language users and the culture keeper. This generation will inherit and pass the language and also introduce it to other people from another culture.

This research dicussed how the young generation (fourty students from two state and two private junior highschool students) of Javanese people as a billingual of Javanese and Indonesian languages maintain the use of the Javanese language (with Semarang dialect) in their speech community (among youth) supported by their language environment (Northern Semarang District) that serves as a part of Javanese culture preservation in Central Java.

\section{Theoretical Background}

\subsection{Culture and Language Environment}

Culture is a whole knowledge of human being as social creature that were used to understand their environment and life experience which is served as a guidance of their behavior and act [2]. With their ability and competence, human being is able to develop various systems of act to fullfil their daily need that must be learned and customized since birth to get the highest performance and the best result.

* Corresponding author: wiekku@yahoo.com 
One of those acts is learning language to communicate, get their need, show their identity and build their cuture. For example, as a Javanese people, someone must be able to speak Javanese language as it is taught by his/her mother as a mother tongue, use it to communicate in Javanese language speech community, and supported by Javanese language environment.

Since keeping the language use will keep the culture, the use of language in its speech community supported by its environment is important to do to keep the culture to avoid the extinction of the language and the culture just like what happened to many indigenous languages in Indonesia.

\subsection{Language Maintenance}

Language maintenance is a result of language selection process in a very long period [3]. It is not only connected with how a certain speech community in a certain language environment maintain their mother tongue, but also related with the attitude toward and the value of a language to be kept using among other languages at the same time. In a multi-language community, a speaker only choose a certain language that give him/her the highest benefit to understand the communication situation in their community and environment.

Therefore, language maintenance does not only happened due to a high loyalty or nationalism in a language as there are many other factores related to language benefit that influence someone to choose a language [4]. However, it does not also mean that a language with high prestige will replace or shift a language with low value as various factors like the change of financial condition, social status, demography and institutional (environment) support will influence their language choice.

\subsection{Billingualism}

The use of two languages/more by a certain society is called billingualism [5]. Billingualism can be seen from someone's speaking competence of the languages, cognitive organization (memory placing of the language in his/her brain) or status of the languages for him/her. As billiguality is measured by someone's competence, if the language competence of the two languages is similar, then his/her billinguality is in balance. However, if the language competence of the first language is more dominant than the second language, then his/her billinguality is dominant [6].

\section{Methodology}

Under sociolinguistics approach, this research discusses the language-use related to its user in the society as a group behavior, not individual [7]. By applying descriptive-qualitative methods, this research is aimed at revealing the Javanese language maintenance -both spoken and written- (Ngoko, Madya, and Krama levels along with the letters and numbers) of fourty students
(Grade VII) from two State and two Private Junior Highschools in Northern Semarang District as Javanese language environment (an area of Javanese language speech community) as the data source which were taken by using Random Sampling Technique [8].

The data were the students' Javanese language competence -both spoken and written- collected by spreading questionnaire [9] which were purposively made for measuring the repondents' language competence and holding an interview [9] with their Javanese language teacher which were designed to dig more information of the respondents' language competence and doing a direct observation [9] on the student's spoken and written production to get the authentic data. The sample were taken from the students' Javanese language production as the population which were obtained using Random Sampling Technique [10]. The data were then analysed by categorizing the Javanese language production into spoken and written and based on the three different Javanese language levels and then describing their language competence as a feature of Javanese language maintenance, as a part of Java culture preservation.

\section{Finding and Discussion}

\subsection{Finding}

Javanese language has three levels of politeness called Ngoko, Madya and Krama [11] as follows.

First Level : Menapa panjenengan badhe dahar (polite) sekul kaliyan kaspe samenika?

Second Level : Napa sampeyan ajeng neda sekul (semi polite) kaliyan kaspe saniki?

Third Level : Apa kowe arep mangan sega lan (casual) kaspe saiki?

The whole level means "Are you goind to eat the rice and kaspe now?"

Javanese language also has certain letters commonly called as hanacaraka as follows.

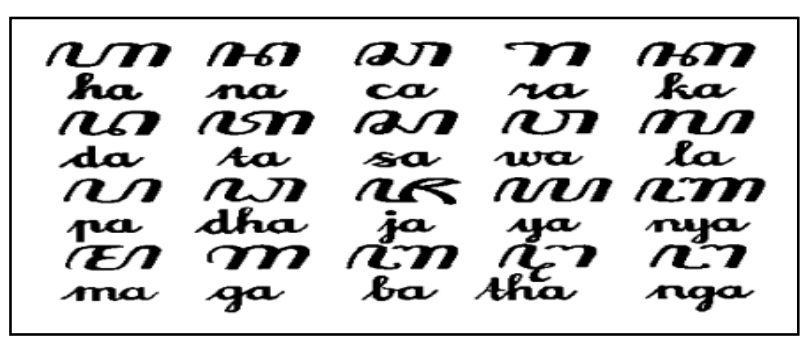

From the data collection, there are four tables that draws the whole finding of the research as follows.

Table 1. Javanese Language Competence of 7th State Junior Highschool

\begin{tabular}{|c|c|c|c|c|c|c|}
\hline \multirow{2}{*}{ No } & Name & \multicolumn{5}{|c|}{ Javanese Language Competence } \\
\cline { 3 - 7 } & (Initial) & Ngoko & Madya & Krama & Number & Writing \\
\hline 1. & MR & - & $\sqrt{ }$ & - & $\sqrt{ }$ & $\sqrt{ }$ \\
\hline 2. & MA & $\sqrt{ }$ & - & - & - & - \\
\hline 3. & AD & - & $\sqrt{ }$ & - & $\sqrt{ }$ & $\sqrt{ }$ \\
\hline 3. & DA & $\sqrt{ }$ & - & - & - & - \\
\hline
\end{tabular}




\begin{tabular}{|c|c|c|c|c|c|c|}
\hline 5. & DF & - & $\sqrt{ }$ & - & - & $\sqrt{ }$ \\
\hline 6. & AI & - & - & $\sqrt{ }$ & $\sqrt{ }$ & $\sqrt{ }$ \\
\hline 7. & AR & - & - & $\sqrt{ }$ & $\sqrt{ }$ & $\sqrt{ }$ \\
\hline 8. & MA & $\sqrt{ }$ & - & - & - & - \\
\hline 9. & AP & $\sqrt{ }$ & - & - & - & - \\
\hline 10. & LM & - & $\sqrt{ }$ & - & - & $\sqrt{ }$ \\
\hline
\end{tabular}

Ngoko: 4, Madya: 4, Krama: 2

From Table 1 we can see that students are able to speak both Ngoko and Madya more than Krama. This figure shows one of their Ngoko.

\section{Tulislah kalima berikut ini dalam Bahasa Jawa :}

a. Temanku sedang tidur. (Jawa Ngoko) boncoke iseh fure

Fig. 1. Javanese Ngoko Level

Table 2. Javanese Language Competence of 25th State Junior Highschool

\begin{tabular}{|c|c|c|c|c|c|c|}
\hline \multirow{2}{*}{ No } & Name & \multicolumn{5}{|c|}{ Javanese Language Competence } \\
\cline { 3 - 7 } & (Initial) & Ngoko & Madya & Krama & Number & Writing \\
\hline 1. & KZ & $\sqrt{ }$ & - & - & - & - \\
\hline 2. & AP & $\sqrt{ }$ & - & - & - & $\sqrt{ }$ \\
\hline 3. & MI & - & $\sqrt{ }$ & - & $\sqrt{ }$ & - \\
\hline 3. & FM & - & $\sqrt{ }$ & - & $\sqrt{ }$ & $\sqrt{ }$ \\
\hline 5. & DP & - & - & $\sqrt{ }$ & $\sqrt{ }$ & $\sqrt{ }$ \\
\hline 6. & RM & $\sqrt{ }$ & - & - & - & - \\
\hline 7. & AN & $\sqrt{ }$ & - & - & - & $\sqrt{ }$ \\
\hline 8. & MY & $\sqrt{ }$ & - & - & - & - \\
\hline 9. & FR & $\sqrt{ }$ & - & - & - & - \\
\hline 10. & GF & $\sqrt{ }$ & - & - & - & - \\
\hline
\end{tabular}

Ngoko: 7, Madya: 2, Krama: 1

From Table 2 we can see that more students are able to speak Ngoko than Madya and Krama. This figure shows one of their Krama.

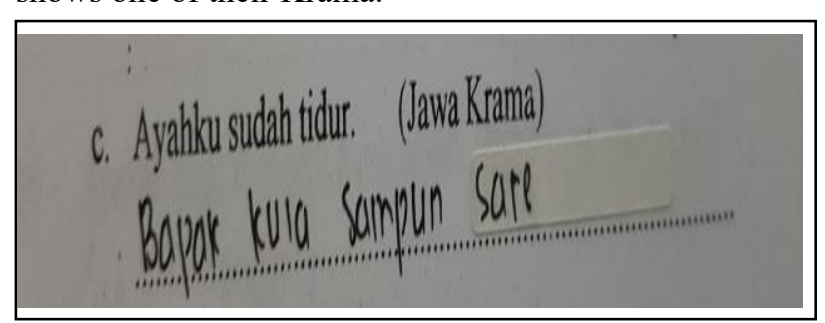

Fig. 2. Javanese Krama Level

Table 3. Javanese Language Competence of Al Kaustar Private Junior Highschool

\begin{tabular}{|c|c|c|c|c|c|c|}
\hline \multirow{2}{*}{ No } & Name & \multicolumn{5}{|c|}{ Javanese Language Competence } \\
\cline { 3 - 7 } & (Initial) & Ngoko & Madya & Krama & Number & Writing \\
\hline 1. & LS & - & $\sqrt{ }$ & - & - & $\sqrt{ }$ \\
\hline 2. & AI & $\sqrt{ }$ & - & - & - & - \\
\hline 3. & RW & $\sqrt{ }$ & - & $\sqrt{ }$ & $\sqrt{ }$ & $\sqrt{ }$ \\
\hline 3. & MR & $\sqrt{ }$ & - & - & - & - \\
\hline 5. & DW & $\sqrt{ }$ & - & - & - & - \\
\hline
\end{tabular}

\begin{tabular}{|c|c|c|c|c|c|c|}
\hline 6. & AN & $\sqrt{ }$ & - & - & $\sqrt{ }$ & $\sqrt{ }$ \\
\hline 7. & MG & $\sqrt{ }$ & - & - & - & - \\
\hline 8. & AF & - & - & - & $\sqrt{ }$ & $\sqrt{ }$ \\
\hline 9. & SM & $\sqrt{ }$ & - & - & $\sqrt{ }$ & $\sqrt{ }$ \\
\hline 10. & MS & $\sqrt{ }$ & - & - & - & - \\
\hline
\end{tabular}

Ngoko: 8, Madya: 1, Krama: 1

From Table 3 we can see that most students are able to speak Ngoko more than Madya and Krama. few of them can produce number in Krama. This figure shows one of their Krama of number.

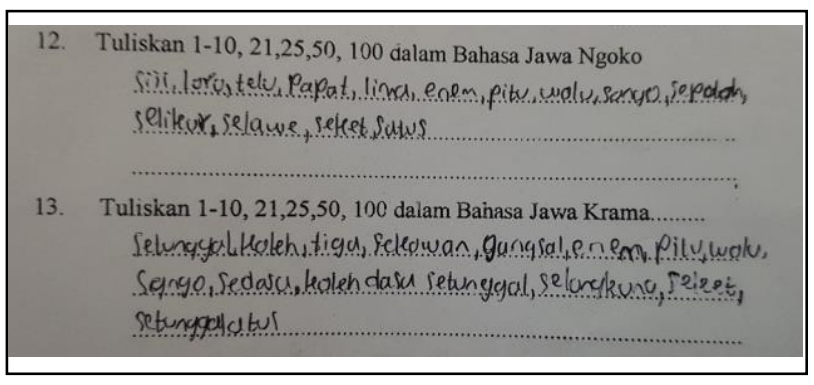

Fig. 3. Number in Javanese Krama Level

Table 4. Javanese Language Competence of 1st Muhammadiyah Private Junior Highschool

\begin{tabular}{|c|c|c|c|c|c|c|}
\hline \multirow{2}{*}{ No } & Name & \multicolumn{5}{|c|}{ Javanese Language Competence } \\
\cline { 4 - 8 } & (Initial) & Ngoko & Madya & Krama & Number & Writing \\
\hline 1. & MN & $\sqrt{ }$ & - & - & - & - \\
\hline 2. & MA & - & - & - & - & $\sqrt{ }$ \\
\hline 3. & CY & $\sqrt{ }$ & - & - & - & - \\
\hline 3. & LA & - & $\sqrt{ }$ & - & $\sqrt{ }$ & $\sqrt{ }$ \\
\hline 5. & AR & - & $\sqrt{ }$ & - & $\sqrt{ }$ & $\sqrt{ }$ \\
\hline 6. & FM & $\sqrt{ }$ & - & - & - & - \\
\hline 7. & DA & - & - & $\sqrt{ }$ & $\sqrt{ }$ & $\sqrt{ }$ \\
\hline 8. & BM & - & $\sqrt{ }$ & - & $\sqrt{ }$ & $\sqrt{ }$ \\
\hline 9. & MF & $\sqrt{ }$ & - & - & - & - \\
\hline 10. & FS & $\sqrt{ }$ & - & - & - & - \\
\hline
\end{tabular}

Ngoko: 5, Madya: 3, Krama: 2

From Table 4 we can see that almost all students are able to speak Ngoko more than Madya and Krama. Some of them can use Javanese letter. This figure shows one of their Javanese letter.

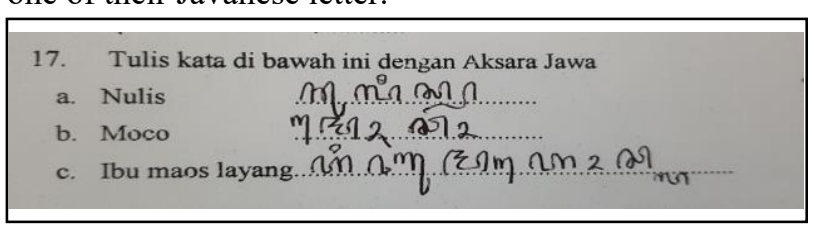

Fig. 4. Javanese Letter

\subsection{Discussion}

\subsubsection{7th State Junior Highshool}

7th State Junior Highschool is located in Imam Bonjol Street, one of Semarang City main streets full of private universities, schools, offices, hotels, shops and restaurants where more people speak Indonesian as an official language used in those places. The students are 
coming from the different area of Semarang City as this school is categorized as favourite school chosen by students from different place in Semarang City including North Semarang. Most of them are able to speak Javanese language as they are origially coming from Semarang.

From the data in Table 1, we can see that four students are able to speak Javanese using the lowest level of Javanese called Ngoko to talk to their friends in casual situation such as during break time at school or in their free time at home. four students are able to speak using the middle level of Javanese called Madya to talk with more polite ways from Ngoko. Two students can use the highest level of Javanese called Krama to talk with older or honorable person.

It is interesting to note that all of them can write using Javanese letters since they were taught by their Javanese language teacher during Javanese language class as an obligatory local content subject for all school in Central and East Java. Eventhough they do not use it in their daily writing affairs, it is good to know that the orthograpic still exist among youth. However, only one of them are able to produce the correct form of Javanese Language particular number both in Ngoko and Krama such as 'selawe-selangkung' for twenty five, 'seket' for fifty and 'satus-setunggal atus' for a hundred.

\subsubsection{5th State Junior Highshool}

25th State Junior Highschool is located in Kuala Mas Street, one of Semarang City housing area not far from the coast that suffer from tidal flood creating slum area around the shcool. Most of people are speaking Javanese language to talk with people at home or arond the negihbourhood. In the school, most of the students are coming from the nearby coastal area of North Semarang whose residences are Javanese originally coming from Semarang who are able to speak Javanese since their mother tongue or first language are Javanese with Semarang Dialect.

From the data in Table 2, we can see that seven students are able to speak Javanese using the lowest level of Javanese called Ngoko to talk to their friends in casual situation such as during break time at school or in their free time at home. Two students are able to speak using the middle level of Javanese called Madya to talk with more polite ways from Ngoko. Only one student can use the highest level of Javanese called Krama to talk with older or honorable person.

Just like 7th State Junior Highschool students, all of them can write using Javanese letters since they were taught by their Javanese language teacher during Javanese language class as an obligatory local content subject for all school in Central and East Java. Eventhough they do not use it in their daily writing affairs, it is good to know that the orthograpic still exist among youth. In addition, five them are able to produce the correct form of Javanese Language particular number both in Ngoko and Krama such as 'selawe-selangkung' for twenty five, 'seket' for fifty and 'satus-setunggal atus' for a hundred.

\subsubsection{Al Kautsar Private Junior Highshool}

Al Kautsar Private Junior Highschool is located in West Brotojoyo Street, dense and simple housing area not far from the coast that also suffer from tidal flood like 25th State Junior Highschool creating slum area around the shcool. Most of people are speaking Javanese language to talk with people at home or arond the negihbourhood. In the school, most of the students are coming from the nearby coastal area of North Semarang whose residences are Javanese originally coming from Semarang who are able to speak Javanese since their mother tongue or first language are Javanese with Semarang Dialect.

From the data in Table 3, we can see that eight students are able to speak Javanese using the lowest level of Javanese called Ngoko to talk to their friends in casual situation such as during break time at school or in their free time at home. Only one student are able to speak using the middle level of Javanese called Madya to talk with more polite ways from Ngoko. Only one student can use the highest level of Javanese called Krama to talk with older or honorable person.

Just like 7th and 25th State Junior Highschool students, all of them can write using Javanese letters since they were taught by their Javanese language teacher during Javanese language class as an obligatory local content subject for all school in Central and East Java. Eventhough they do not use it in their daily writing affairs, it is good to know that the orthograpic still exist among youth. In addition, five them are able to produce the correct form of Javanese Language particular number both in Ngoko and Krama such as 'selawe-selangkung' for twenty five, 'seket' for fifty and 'satus-setunggal atus' for a hundred.

\subsubsection{1st Muhammadiyah Private Junior Highshool}

1st Muhammadiyah Private Junior Highschool is located in Indraprasta Street, one of Semarang City main streets full of schools, offices, hotels, shops and restaurants where more people speak Indonesian as an official language used in those places. The students are coming from the different area of Semarang City as this school is categorized as favourite school chosen by students from different place in Semarang City including North Semarang. Most of them are able to speak Javanese language as they are origially coming from Semarang.

From the data in Table 4, we can see that five students are able to speak Javanese using the lowest level of Javanese called Ngoko to talk to their friends in casual situation such as during break time at school or in their free time at home. Three students are able to speak using the middle level of Javanese called Madya to talk with more polite way from Ngoko. Two students can use the highest level of Javanese called Krama to talk with older or honorable person.

Just like 7th and 25th State Junior Highschool and Al Kautsar Private Junior Highschool students, all of them can write using Javanese letters since they were taught by their Javanese language teacher during Javanese language class as an obligatory local content subject for all school in Central and East Java. Eventhough they do 
not use it in their daily writing affairs, it is good to know that the orthograpic still exist among youth. In addition, two them are able to produce the correct form of Javanese Language particular number both in Ngoko and Krama such as 'selawe-selangkung' for twenty five, 'seket' for fifty and 'satus-setunggal atus' for a hundred.

The whole result shows that the sudents still use Javanese language eventhough their language competence are more limited on the lowest level of Javanese language called Ngoko. Some of them still understand the Madya level as it is often used to honor people when they do not understand how to use the Krama level.

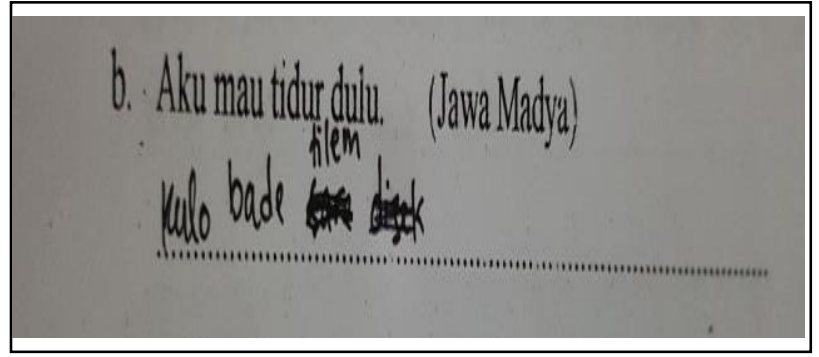

Fig. 5. Javanese Madya Level

The Krama level is rarely used -including the Krama level number- since their speech community outside Javanese language class supports them to use Ngoko and Madya levels among friends and older person as Semarang particularly Northern Semarang which is located near coastal area is known for its language environment of Ngoko Javanese with Semarang Dialect which sometimes consider rude or impolite for Javanese people who normally used Yogyakarta or Surakarta Javanese Dialects.

Related to Javanese language letters, all of them are becoming passive writers as it is only used during Javanese language class at school. Thus, some of them can use it correctly, but other still produce minor errors like the sound adding, the number and the punctuation errors.

Related to he phenomenon of bilingualism of Javanese and Indonesian languages, it can be said that they are balance-bilingual as they are able to use both languages interchangeably, both spoken and written, including the use of number and letter.

Based on the interview with the teachers, to preserve Javanese language as a part of Javanese culture and to avoid the proverb saying 'wong nJowo ning ora nJawani' meaning 'Javanese people who do not look, sound, and act like Javanese people', the school creates Javanese language environment by stimulating, endorsing and supporting their students to use the language inside and outside the Javanese language subject in the classroom. To make it interesting and fun, Javanese language teachers gives them fun classroom activities like lesson with interesting teaching aids, practice and game. The school also helps students to use it outside the classroom by holding Javanese language day after English day and giving example of how to speak politely with older or honorable person like teacher, staff, parents, senior, canteen owner, cleaning service, and security.

\section{Conclusion}

There are six conclusions that can be drawn from the finding and discussion in the previous section. First, in Semarang City as the capital city of Central Java Province, particularly in North Semarang as one of Javanese language environment with Semarang dialect, the usage of Javanese language is still maintained by the young generation such as junior highscool students.

Second, most of them are highly competence on the use of the lowest level of Javanese language called the Ngoko level to talk with their friends. Three, it happens as Semarang City, unlike Yogyakarta or Surakarta Cities known for its polite usage of Javanese language, is known as a city with Javanese language Ngoko level which considers rude or impolite for people who are commonly using Javanese language with Yogyakarta or Surakarta dialects. However, instead of being considered as rude or impolite, it is considered normal as it shows a high intimacy among speakers just like the use of East Javanese language Ngoko level in talking and even cursing.

Four, to preserve and develop the Javanese language competence, it is beneficial to stimulate, trigger, endorse, empower and support the Javanese language usage in their own way like in the social media content such as local comedy vlog or personal blog with local content. It is also beneficial to keep teaching it at school as a subject with local content so that the young generation who will be the future generation preserving the language and the culture is ready to carry on the responsibility.

Five, the Javanese language preservation is not only subjected to the young generation as the future users of the language and the school as the media educating them, but also parents as their first language teacher, the society as the language environment, and of course the government as the authority that is able to produce rules governming the language preservation.

Last but not least, the preservance of Javanese culture through the maintenance of Javanese language among the young generation is beneficial to develop and support tourism industry which nowadays change its focus on cultural, historical and traditional tourism business by using local content [12] such as Javanese culture, language and tradition.

\section{References}

1. Koentjaraningrat, Pengantar Ilmu Antropologi, Jakarta, PT. Rineka Cipta (1990)

2. M. Al-Barry and Dahlan Yacub, Kamus Sosiologi Antropologi, Surabaya, PT. Indah (2001)

3. V. John Edwards, Foundations of Bilingualism, Bhatia K. Tej et.al. (editor), Chicerter: WileyBlackwell (2008) 
4. Josiane F. Hammer and Michel H. Blanc, Bilingualism and Bilinguality, Cambridge: Cambridge University Press (1998)

5. Ralp Fasold, The Sociolinguictis of Society, New York, Basil Blackwell Ltd (1987)

6. Joshua A Fishman, Sociolinguistics: A Brief Introduction to Sociolinguistics, New York, Blackwell (1972)

7. Ronald Wardhaugh and Janet M. Fuller, An Introduction to Sociolinguistics. New York, Blackwell (2015)

8. Sudaryanto, Metode dan Aneka Teknik Analisis Bahasa: Pengantar Penelitian Wacana Kebudayaan secara Linguistik, Yogyakarta: Duta Wacana (2013)

9. Suharsimi Arikunto, Prosedur Penelitian: Suatu Pendekatan Praktik, Jakarta, PT Rineka Cipta (2006)

10. Sugiyono, Metode Penelitian Kualitatif dan $R \& D$, Bandung, CV Alfabeta (2010)

11. Clifford Geertz, The Religion Of Java, Terjemahan Abangan, Santri, Priyayi Dalam Masyarakat Jawa. Jakarta, PT. Dunia Pustaka Jaya (1989)

12. Lara L. Hill, Indigenous Culture: both malleable and valuable, Emeral Insight. International Journal of Culture, Tourism and Hospitality Research, 5 (2011) 